that intrauterine placental transfusion may occur in the asphyxiated foetus.

The mechanism(s) of this intrauterine placental transfusion is (are) unclear. Foetal distress and asphyxia were documented clinically in the majority of our infants. In the presence of asphyxia $p \mathrm{H}$ and $\mathrm{PO}_{2}$ fall while $\mathrm{PCO}_{2}$ rises. It is possible that these changes induced respiratory movements in utero (King and Becker, 1964). This intrauterine respiratory activity could then have facilitated the occurrence of placental transfusion on a basis similar to that which occurs with the onset of extrauterine respiration.

In the complex foeto-placental circulation a shift of blood from the placenta to the foetus must involve more flow through the umbilical vein than arteries, otherwise no net transfer of blood could result. In this context the mechanisms underlying our "pathological" placental transfusion may involve factors increasing umbilical venous return or factors decreasing umbilical artery output. The hypoxic induction of uterine contractions could cause placental blood to flow into the foetus. Asphyxia would cause the foetal adrenal glands to secrete earecholamines (Comline and Silver, 1966), which if present in large enough quantities may produce umbilical artery vasoconstriction. The physiological role of thermal factors, mechanical factors, or humoral agents, such as serotonin, bradykinin, and prostaglandins, in umbilical artery constriction after delivery is controversial, hence their function in intrauterine placental transfusion is totally unclear.

The data obtained in the present study raise several questions and reopen several areas of perinatal investigation. Does this pathological prenatal placental transfusion play any significant part in perinatal pathology? Our asphyxiated babies had an uneventful neonatal course. On the other hand, the asphyxiated babies of Burnard and James (1963) had cardiac dilatation and heart failure and may have had a large intrauterine placental transfusion. In addition, neonatal erythrocythaemia (O'Connor et al., 1968) and transient tachypnoea of the newborn (Avery et al., 1966) which has pulmonary radiological features similar to neonatal erythrocythaemia (O'Connor et al., 1968) may be in part produced by the same mechanism.

Other unanswered questions would include: What is the frequency of a prenatal placental transfusion? Does it occur under circumstances other than asphyxia? Does it always occur with asphyxia? Although asphyxia is a frequent antecedent of the respiratory distress syndrome, the haematocrit in this syndrome tends to be in the low normal range, an observation which suggests that an intrauterine placental transfusion did not take place (Inall et al., 1965). Further studies are needed to answer these questions.

This work was aided by a grant from the National Foundation. We would like to thank Dr. David Charles and the Obstetrical Service at the Boston City Hospital for their co-operation in performing this study. We are indebted to Drs. Horace M. Gezon, Robert Klein, Thomas Gardner, and Joseph D. Sherman for their stimulating criticisms in the preparation of this paper.

\section{REFERENCES}

Avery, M. E., Gatewood, O. B., and Brumley, G. (1966). American fournal of Diseases of Children, 111, 380 .

Burnard, E. D., and James, L. S. (1963). Fournal of Pediatrics, 62, 815. Comline, R. S., and Silver, M. (1966). British Medical Bulletin, 22, 16. Gunther, M. (1957). Lancet, 1, 1277.

Inall, J. A., Bluhm, M. M., Kerr, M. M., Douglas, T. A., Hope, C. S. and Hutchison, J. H.' (1965). Archives of Diseases in Childhood, 40, 480 .

King, J. E., and Becker, R. F. (1964). American fournal of Obstetrics and Gynecology, 90, 257.

Kjeldsen, J., and Pedersen, J. (1967). Lancet, 1, 180.

Moss, A. J., and Monset-Couchard, M. (1967). Pediatrics, 40, 109

Nyberg, R., and Westin, B. (1958). Acta paediatrica, 47, 350 .

O'Connor, J. F., Shapiro, J. H., and Ingall, D. (1968). Radiology, 90, 333.

Redmond, A., Isana, S., and Ingall, D. (1965). Lancet, 1, 283.

Yao, A. C., Wist, A., and Lind, J. (1967). Acta paediatrica, 56, 585.

\title{
Weight-reducing Effect of Diguanides in Obese Non-diabetic Women
}

\author{
J. F. MUNRO,* M.B., M.R.C.P.ED. ; A. C. MACCUISH, $\dagger$ M.B., M.R.C.P.ED. \\ A. MARSHALL, $\ddagger$ M.B., B.SC., M.R.C.P.ED. ; ELIZABETH M. WILSON,§ S.R.D. \\ L. J. P. DUNCAN,\| M.B., B.SC., F.R.C.P.ED.
}

British Medical fournal, 1969, 2, 13-15

\begin{abstract}
Ummary : A double-blind trial was carried out to assess the weight-reducing effect of the diguanides in $\mathbf{9 0}$ women with refractory obesity and normal oral glucose tolerance. The daily dosage of phenformin and metformin was increased at weekly intervals up to $300 \mathrm{mg}$. and $3 \mathrm{~g}$. respectively, and patients were maintained at this dose or on the maximum they could tolerate without anorexia or other gastrointestinal side-effects. Seventyseven completed the 16-week period of study. There was a statistically significant difference between the mean weight change of the control and the treated groups, but no difference between those treated by phenformin or metformin. The weight-losing influence of the diguanides appeared to be no longer significant after the twelfth week of treatment.
\end{abstract}

\section{Introduction}

Obese insulin-independent diabetics uncontrolled by attempted dieting generally gain weight when treated with a sulphonylurea but lose weight when given a diguanide (Clarke and Duncan, 1968). The present study was undertaken to determine whether or not the diguanides have a weight-reducing influence in obese non-diabetic patients.

\section{Material and Methods}

Ninety-six women aged 21 to 63 years were invited to participate. All had refractory obesity, were clinically obese and overweight by at least $20 \%$ of their ideal, had regularly attended the department for 12 months or more, and had not received an anoretic drug, or appreciably lost weight during the three months preceding the study. None had oedema or was known to have cardiac disease.

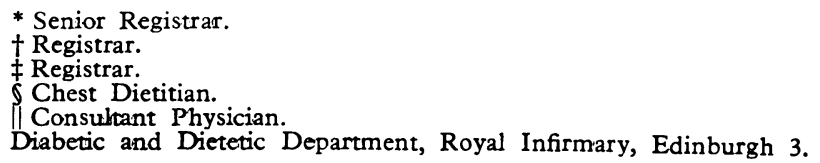


A standard oral glucose tolerance test was performed on each patient. Five were found to be diabetic and a sixth was excluded because she became too heavy to weigh on the clinic scales. The remaining 90 patients were divided into three groups comparable for age and body weight. One group received phenformin (Dibotin) 50-mg. sustained release capsules, the second metformin (Glucophage) $0.5-\mathrm{g}$. tablets, and the third group was subdivided, half being given placebo capsules and the other half placebo tablets, each being identical in appearance to the active preparations.

At the beginning of the trial patients were instructed to take one capsule or tablet daily with or immediately after food, and to increase the dose by one capsule or tablet at weekly intervals either until they were taking six daily or until they experienced side-effects or subjective anorexia. They were told of the possible side-effects and asked to reduce the dose immediately if these proved troublesome or persisted for longer than one week.

Patients were weighed and asked to attend a special clinic at two-weekly intervals for 16 weeks, wearing as nearly as possible the same clothes. At each subsequent visit they were weighed, interviewed, specifically asked about side-effects, and given a further supply of tablets or capsules, the nature of which was unknown both to them and to the interviewing doctor. Blood was withdrawn for estimation of the plasma bicarbonate level at every visit, and at random intervals the blood glucose concentration was also estimated, though it is established that the diguanides do not lower the blood glucose of non-diabetics (Kreisberg, 1968).

\section{Results}

Thirteen patients did not complete the study; seven defaulted from follow-up, one left the district, one was admitted to hospital with an acute urinary infection, and four were withdrawn because they experienced side-effects while taking only one capsule or tablet daily. The relevant clinical data of the remaining 77 and the results of treatment are given in Table I; this also shows that they formed three comparable groups with regard to age, ideal weight, initial weight, and weight gain during the preceding three months.

There was no difference between the mean weight response to dummy capsules $(+2 \cdot 8 \mathrm{lb}$. $)$ and dummy tablets $(+2 \cdot 5 \mathrm{lb}$. $)$, the mean gain of all patients taking a placebo being statistically significant $(t=2.4, \mathrm{P}<0.05)$ and similar to that preceding the trial. Similarly the mean weight change at 16 weeks of patients taking phenformin $(-7.3 \mathrm{lb}$.) was much the same as that of those taking metformin $(-6.5 \mathrm{lb}$.), the change being statistically significant in both groups (for phenformin $t=5 \cdot 3$, for metformin $t=4 \cdot 7$, and for both $\mathrm{P}<0 \cdot 001$ ). Eighty per cent. of the patients on diguanide lost weight, whereas only $37 \%$ of those on dummies did so. It is difficult to determine if or when the weight-reducing influence of the diguanides ends, but analysis by the median test for significance (Siegel, 1956) suggests that it is lost at about the twelfth week (Table I).

The mean weight change during treatment with a diguanide of the 15 patients who gave a history of diabetes in a first- of second-degree relative or who had given birth to a child weighing more than $10 \mathrm{lb} .(-6.8 \mathrm{lb}$. S.D. 8.4$)$ did not differ statistically from the mean weight change of the 35 who gave no such history $(-7 \cdot 1$ lb. S.D. 6.5).

Twenty-two per cent. of patients receiving placebo and $90 \%$ of those given the diguanides said they had experienced gastrointestinal disturbances (Table II). There was no difference between the frequency of the various side-effects in those treated with phenformin and metformin. Table III shows that, in terms of numbers of phenformin capsules or metformin tablets taken each day, gastrointestinal side-effects were less readily elicited by metformin, which was also the better tolerated. However, though the number of phenformin capsules taken daily was less than that of metformin tablets, it should be noticed that the effect on weight was the same and that the doses were of equivalent hypoglycaemic potency in the diabetic.

TABLE II.-Nature of Side-effect. Number of Patients Indicated in Columns; Last Column Gives Percentage of Patients Treated with a Diguanide

\begin{tabular}{|c|c|c|c|c|}
\hline & \multicolumn{4}{|c|}{ Treatment } \\
\hline & Placebo & Phenformin & Metformin & $\begin{array}{c}\text { Diguanide } \\
(\%)\end{array}$ \\
\hline \multirow{5}{*}{ 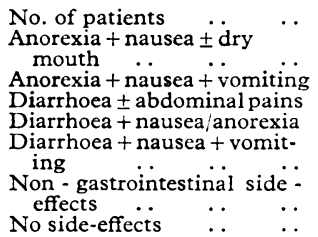 } & 27 & 24 & 26 & \\
\hline & 3 & 7 & 9 & \\
\hline & $\frac{1}{2}$ & $\begin{array}{l}5 \\
1 \\
6\end{array}$ & $\begin{array}{l}5 \\
2 \\
4\end{array}$ & $\begin{array}{r}20 \\
6 \\
20\end{array}$ \\
\hline & & 3 & 3 & 12 \\
\hline & $\begin{array}{r}2 \\
19\end{array}$ & $\begin{array}{l}1 \\
1\end{array}$ & $\frac{1}{2}$ & \} 10 \\
\hline
\end{tabular}

TABLE III.-Dose of Diguanide Required to Produce Gastrointestinal Symptoms and the Maximum Dose Tolerated. Number of Patients: Indicaied in the Columns

\begin{tabular}{|c|c|c|c|c|c|}
\hline \multicolumn{3}{|c|}{ Phenformin (24) } & \multicolumn{3}{|c|}{ Metformin (26) } \\
\hline Daily Dose & $\begin{array}{c}\text { G.I. } \\
\text { Symptoms }\end{array}$ & Tolerated & $\begin{array}{l}\text { Daily } \\
\text { Dose }\end{array}$ & $\begin{array}{c}\text { G.I. } \\
\text { Symptoms }\end{array}$ & Tolerated \\
\hline $\begin{array}{l}100 \mathrm{mg} \text {. or less } . . \\
150 \text { or } 200 \mathrm{mg} . \\
250 \text { or } 300 \mathrm{mg} . \\
\text { No G.I. symptoms } \\
\text { on maximal dos- } \\
\text { age .. }\end{array}$ & $\begin{array}{r}1 \\
9 \\
12 \\
\\
2\end{array}$ & $\begin{array}{r}1 \\
15 \\
8\end{array}$ & $\begin{array}{l}1 \mathrm{~g} \text {. or less } \\
1.5 \text { or } 2 \mathrm{~g} . \\
2.5 \text { or } 3 \mathrm{~g} .\end{array}$ & $\begin{array}{r}1 \\
2 \\
20\end{array}$ & $\begin{array}{r}1 \\
6 \\
19\end{array}$ \\
\hline
\end{tabular}

Nine patients taking a diguanide and one patient taking a placebo had a plasma bicarbonate of less than $20 \mathrm{mEq} / \mathrm{l}$. This was an isolated finding except in one patient who had two consecutive readings of $15 \mathrm{mEq} / 1$. and $16 \mathrm{mEq} / \mathrm{l}$. when taking three capsules of sustained release phenformin daily. Hypoglycaemia was not encountered.

Table I.-Clinical Data and Results of Treatment of Subjects Completing the Study (Mean, S.D., and Range)

\begin{tabular}{|c|c|c|c|c|c|c|c|c|c|c|c|c|c|c|c|c|c|}
\hline \multirow{3}{*}{ Treatment } & \multicolumn{17}{|c|}{ Subjects Completing the 16-week Study } \\
\hline & \multirow{2}{*}{ Age } & \multirow{2}{*}{$\begin{array}{c}\text { Weight } \\
\text { Change } \\
\text { in } 3 \\
\text { Months } \\
\text { before } \\
\text { (lb.) }\end{array}$} & \multirow{2}{*}{$\begin{array}{c}\text { Standard } \\
\text { Weight } \\
\text { (lb.) }\end{array}$} & \multicolumn{2}{|c|}{ Excess Weight as } & \multicolumn{9}{|c|}{ Weight Change per Two-weekly Period (lb.) } & \multicolumn{3}{|c|}{$\begin{array}{l}\text { Weight Change. } \\
\text { No. of Patients }\end{array}$} \\
\hline & & & & lb. & $\%$ Ideal & 1 & 2 & 3 & 4 & 5 & 6 & 7 & 8 & Total & Nil & Gain & Loss \\
\hline $\begin{array}{l}\text { Inactive placebo } \\
(27 \text { cases })\end{array}$ & $\begin{array}{c}42 \\
21-63\end{array}$ & $\begin{array}{r}+3-5 \\
(2 \cdot 9) \\
+9 \text { to } \\
-2\end{array}$ & $\begin{array}{c}140 \\
(9 \cdot 9) \\
158-118\end{array}$ & $\begin{array}{c}64 \\
(23) \\
124-27\end{array}$ & $\begin{array}{c}46 \\
(18) \\
89-22\end{array}$ & $\begin{array}{c}+0 \cdot 3 \\
(2 \cdot 6) \\
+6 \text { to } \\
-5\end{array}$ & $\begin{array}{c}+0.4 \\
(1.8) \\
+4 \text { to } \\
-3\end{array}$ & $\begin{array}{c}+0.4 \\
(2 \cdot 0) \\
+4 \text { to } \\
-3\end{array}$ & $\begin{array}{c}+0.6 \\
(2 \cdot 2) \\
+6 \text { to } \\
-3 \\
\end{array}$ & $\begin{array}{c}+0.3 \\
(1.7) \\
+5 \text { to } \\
-3 \\
\end{array}$ & $\begin{array}{c}+0.3 \\
(1.7) \\
+4 \text { to } \\
-5 \\
\end{array}$ & $\begin{array}{c}-0.1 \\
(1.8) \\
+3 \text { to } \\
-4\end{array}$ & $\begin{array}{c}+0.3 \\
(2 \cdot 1) \\
+6 \text { to } \\
-3\end{array}$ & $\begin{array}{c}+2 \cdot 6 \\
(5 \cdot 1) \\
+10 \text { to } \\
-11\end{array}$ & 1 & 16 & 10 \\
\hline $\begin{array}{l}\text { Phenformin } \\
\text { capsules } \\
\text { (24 cases) }\end{array}$ & $\begin{array}{c}44 \\
22-61\end{array}$ & $\begin{array}{c}+2 \cdot 8 \\
(4 \cdot 0) \\
+13 \text { to } \\
-4 \\
\end{array}$ & $\begin{array}{c}141 \\
(9 \cdot 6) \\
160-120\end{array}$ & $\begin{array}{c}64 \\
(30) \\
172-31\end{array}$ & $\begin{array}{c}46 \\
(22) \\
126-21\end{array}$ & $\begin{array}{c}+0.4 \\
(1.9) \\
+5 \text { to } \\
-2 \\
\end{array}$ & $\begin{array}{c}-1.6 \\
(1.6) \\
+1 \text { to } \\
-5 \\
\end{array}$ & $\begin{array}{c}-1 \cdot 3 \\
(2 \cdot 3) \\
+4 \text { to } \\
-4 \\
\end{array}$ & $\begin{array}{c}-1 \cdot 8 \\
(2 \cdot 4) \\
+2 \text { to } \\
-8 \\
\end{array}$ & $\begin{array}{c}-1 \cdot 1 \\
(2 \cdot 0) \\
+2 \text { to } \\
-4 \\
\end{array}$ & $\begin{array}{c}-1.5 \\
(1.8) \\
+2 \text { to } \\
-4 \\
\end{array}$ & $\begin{array}{c}-1 \cdot 2 \\
(2 \cdot 7) \\
+4 \text { to } \\
-5 \\
\end{array}$ & $\begin{array}{c}+0 \cdot 7 \\
(2 \cdot 1) \\
+6 \text { to } \\
-3 \\
\end{array}$ & $\begin{array}{l}-7 \cdot 3 \\
(6 \cdot 8) \\
+9 \text { to } \\
-19 \\
\end{array}$ & 1 & 3 & 20 \\
\hline $\begin{array}{l}\text { Metformin tablets } \\
\text { (26 cases) }\end{array}$ & $\begin{array}{c}43 \\
21-62\end{array}$ & $\begin{array}{l}+4 \cdot 0 \\
(2 \cdot 6) \\
+9 \text { to } \\
0\end{array}$ & $\begin{array}{c}138 \\
(12 \cdot 8) \\
174-114\end{array}$ & $\begin{array}{c}61 \\
(27) \\
138-32\end{array}$ & $\begin{array}{c}45 \\
(19) \\
98-23\end{array}$ & $\begin{array}{c}-0.9 \\
(2.2) \\
+2 \text { to } \\
-7\end{array}$ & $\begin{array}{c}-1 \cdot 2 \\
(2 \cdot 6) \\
+4 \text { to } \\
-7\end{array}$ & $\begin{array}{c}-1.5 \\
(2 \cdot 7) \\
+5 \text { to } \\
-7\end{array}$ & $\begin{array}{c}-1 \cdot 2 \\
(1 \cdot 6) \\
+2 \text { to } \\
-4\end{array}$ & $\begin{array}{c}-0.4 \\
(1.8) \\
+3 \text { to } \\
-4\end{array}$ & $\begin{array}{c}-0.4 \\
(1.8) \\
+4 \text { to } \\
-3\end{array}$ & $\begin{array}{c}-0.6 \\
(2 \cdot 0) \\
+5 \text { to } \\
-5\end{array}$ & $\begin{array}{c}-0.3 \\
(2 \cdot 4) \\
+5 \text { to } \\
-5\end{array}$ & $\begin{array}{l}-6 \cdot 5 \\
(7 \cdot 1) \\
+3 \text { to } \\
-23\end{array}$ & 1 & 5 & 20 \\
\hline
\end{tabular}




\section{Discussion}

It has been previously suggested that any weight-reducing effect of phenformin in non-diabetic obese patients is confined to those with a family history of diabetes (Roginsky and Sandler, 1968). The present study, however, shows that both phenformin and metformin, when given in substantial dosage, have weight-reducing properties in non-diabetic patients, irrespective of the family history.

Some of the weight loss may have resulted from reduced food intake; the nature of the study was such that almost all patients receiving a diguanide experienced either nausea or anorexia, but these were either transient or abolished by appropriate reduction of the daily dosage. Other alternatives include the possibility that diguanide treatment causes a reduction in alimentary absorption of glucose, but the present evidence for this is conflicting (Czyzyk et al., 1968 ; Pedersen and Olesen, 1968). If reduction in food intake or food absorption is not the cause of the weight loss then treatment with diguanides may accelerate some catabolic process. It has been shown that they increase the peripheral utilization of glucose in the non-diabetic (Searle and Cavalieri, 1968 ; Kreisberg, 1968). This finding, however, has not been confirmed by others (Butterfield and Whichelow, 1968). The cause of the weight loss cannot be established until the various effects of the diguanides have been more fully elucidated.

From the practical point of view the mean weight loss during diguanide treatment was similar to that obtained by dextroamphetamine and some of its congeners in comparable patients with refractory obesity (Duncan et al., 1960 ; Seaton et al., 1961, 1964a, 1964b; Munro et al., 1966). As with these drugs, the weight-reducing effect of the diguanide may be temporary, but a longer study is required to establish this point. There is clearly no danger of central nervous system stimulation or addiction with diguanide treatment, but it is not without hazard, particularly in patients with appreciable renal, hepatic, or cardiovascular disease, since lactic acidosis can occur and fatalities have been attributed to phenformin administration (Tranquada et al., 1963 ; Young and Armanino, 1965 ; Proctor and Stowers, 1967). One patient in the present study had a significant fall in serum bicarbonate; though this may not reflect a rising serum lactate level, it would seem prudent to monitor serum bicarbonate levels at least while the dose of diguanide is being increased.

\section{REFERENCES}

Butterfield, W. J. H., and Whichelow, M. J. (1968). Lancet, 2, 785. Clarke, B. F., and Duncan, L. J. P. (1968). Lancet, 1, 123. Czyzyk, A., Tawecki, J., Sadowski, J., Ponikowska, I., and Szezepanik, Z. (1968). Diabetes, 17, 492.

Duncan, L. J. P., Rose, K., and Meiklejohn, A. P. (1960). Lancet, 1, 1262 .

Kreisberg, R. A. (1968). Diabetes, 17, 481.

Munro, J. F., Seaton, D. A., and Duncan, L. J. P. (1966). British

, J., and Olesen, E. S. (1968). Acta endocrinologica, 57, 683 Proctor, D. W., and Stowers, J. M. (1967). British Medical Fournal, 4, 216.

Roginsky, M. S., and Sandler, J. (1968). Annals of the New York Academy of Sciences, 148, 892

Searle, G. L., and Cavalieri, R. R. (1968). Annals of the New York

Academy of Sciences, 148, 734.
Seaton, D. A., Duncan, L. J. P., Rose, K., and Scott, A. M. (1961). British Medical fournal, 1, 1009.

Seaton, D. A., Rose, K., and Duncan, L. J. P. (1964a). Scottish Medical fournal, 9, 482 .

Seaton, D. A.', Rose, K., and Duncan, L. J. P. (1964b). Practitioner, 193, 698.

Siegel, S. (1956). Nonparametric Statistics for the Behavioral Sciences, p. 111. McGraw Hill, New York.

Tranquada, R. E., Bernstein, S., and Martin, H. E. (1963). Fournal of the American Medical Association, 184, 37.

Young, J. M., and Armanino, L. P. (1965). California Medicine, 103, 198.

\title{
Clotting Problems with the Teflon-Silastic Arteriovenous Shunt in Patients on Regular Haemodialysis
}

\author{
M. PAPADIMITRIOU,* M.D. ; R. N. P. CARROLL, $\dagger$ B.SC., F.R.C.S.ED. \\ A. E. KULATILAKE, $\ddagger$ F.R.C.s., F.R.C.S.ED.
}

[With Special Plate Between Pages 32 and 33]

British Medical Fournal, 1969, 2, 15-17

Summary: Episodes of clotting that occurred in 22 1 patients on regular haemodialysis were studied over a six-month period. The venous pressure during dialysis and the radiology of the Teflon-Silastic arteriovenous shunt were found to be satisfactory guides for the management of the shunt. The failure of the shunt during the early stage was mainly due to technical reasons. Histological study of the excised vessels in removed long-term shunts showed that these had failed because of rigidity and thickening of the vessel wall due to calcium and iron deposits or chronic inflammation, or both.

\section{Introduction}

The survival of the arteriovenous Teflon-Silastic shunt of the Scribner type depends on the attention to detail both in tech- nique of insertion and in its subsequent management. Of the many complications that develop-that is, infection, skin necrosis, herniation of the Silastic tubing, and bleeding from the shunt wound-the commonest is clotting (Pendras and Erickson, 1966; Shaldon, 1966; Glashan and Walker, 1968). Repeated resiting of the shunt owing to clotting and total occlusion can be a significant factor in the prognosis of many patients, especially those with hypoplastic blood-vessels. To this end anticoagulants (Wing et al., 1967) and fibrinolytic agents (Anderson et al., 1968 ; Kjellstrand et al., 1968) have been tried successfully in many instances, but these agents are by no means free from side-effects.

* Honorary Registrar and NATO Scholar.

† Surgical Registrar.

¥ Senior Registrar in Urology and Tutor in Surgery.

rtificial Kidney Unit, Department of Surgery, Royal Postgraduate Medical School, Hammersmith Hospital, London W.12. 